\title{
EFEKTIVITAS PENERAPAN METODE DISKUSI DENGAN PENDEKATAN MATEMATIKA REALISTIK (PMR) DITINJAU DARI TIPE KEPRIBADIAN SISWA KELAS VIII SMP NEGERI DI KABUPATEN LAMPUNG TIMUR
}

\author{
Desty Septianawati \\ IKIP PGRI Pontianak \\ E-mail: desty.septianawati.a@gmail.com
}

\begin{abstract}
The aims of this research are to know: (1) Which one more effective, learning using discussion with realistic mathematics approach or a conventional learning. (2) Which one gives better mathematics learning achievement, student with personality types Sanguine or Phlegmatis. (3) Which one more effective for each personality typeof students, learning using discussion withPMR or a conventional learning. This research used quasi experimental method with its population included all of students of state junior high school in East Lampung Regency. Sampling was done by stratified cluster random sampling. The size of the samples was 202 students. The data collection technique were the document that was the last of examination theseven grade for initial capability data before the experiment, achievement tests for mathematics student achievement data, and questioner of personality types. The data was analyzed using analysis of variance. The conclusions of the research were as follows: (1) learning mathematics using discussion with PMR is more effective than learning mathematics usingdiscussion with conventional approach. (2) Students with personalitytypesof Sanguinenor Phlegmatis have the same mathematics achievement. (3) For each personality type of students, learning using discussion with PMR approach is more effective than learning mathematics the method of discussion withconventional approach.
\end{abstract}

Keywords: Realistic Mathematics Approach, Personality Types: Sanguine and Phlegmatis

\section{PENDAHULUAN}

Dalam menghadapi era globalisasi yang ditandai dengan pesatnya perkembangan ilmu pengetahuan dan teknologi, diperlukan sumber daya manusia yang handal dan mampu berkompetisi secara global. Sumber daya manusia yang berkualitas memiliki keterampilan berpikir dan dapat diandalkan, meliputi berpikir kritis, sistematis, logis, kreatif, mampu bekerja sama dengan baik, dan mampu memecahkan masalah dalam kehidupan 
dengan ide-ide cemerlang. Cara berpikir dan bernalar dalam pembelajaran matematika sangatlah penting. Hal ini sejalan dengan pendapat R. Soedjadi (2000: 45) bahwa "salah satu karakteristik matematika adalah berpola pikir deduktif yang merupakan salah satu tujuan yang bersifat formal, yang memberi tekanan kepada penataan nalar." Di samping cara berpikir, dalam proses pembelajaran siswa juga dilatih untuk mengembangkan kreativitasnya melalui imajinasi dan intuisi. Hal tersebut dapat dimengerti bahwa matematika itu bukan saja dituntut sekedar menghitung, tetapi siswa juga dituntut agar lebih mampu menghadapi berbagai masalah dalam kehidupan sehari-hari, baik masalah mengenai matematika itu sendiri maupun masalah dalam ilmu lain, serta dituntut suatu disiplin ilmu yang sangat tinggi.

Kenyataan yang sering dijumpai pada umumnya di sekolah menengah pertama menunjukkan bahwa pembelajaran matematika diberikan secara klasikal melalui ceramah dan menggunakan pendekatan mekanistik tanpa melihat kemungkinan penerapan pendekatan lain sesuai dengan materi yang diajarkan. Akibatnya, siswa kurang berminat untuk mengikuti pelajaran yang disampaikan guru, siswa tidak tertarik mengikuti pelajaran, dan tidak adanya kesadaran akan pentingnya pelajaran matematika. Hal ini salah satu penyebab kemampuan matematika siswa rendah. Seperti penelitian yang dilakukan oleh FezaPiyose (2012: 62) yang menyimpulkan bahwa terdapat dua faktoryang dianggap menghambat pembelajaran matematika: pengetahuan guru danstrategi mengajar yang tidak relevan.

Situasi demikian juga terjadi di SMP Negeri se-Kabupaten Lampung Timur. Beberapa guru di sekolah yang berbeda mengungkapkan bahwa pembelajaran matematika yang digunakan sebatas penjelasan materi, pemberian contoh, dan penyelesaian soal-soal. Situasi demikian cenderung membuat siswa menjadi kurang aktif, kreatif, dan kritis dalam pembelajaran. Penguasaan dan pemahaman siswa terhadap konsep-konsep matematika lemah karena tidak mendalam. Akibatnya, prestasi belajar matematika siswa rendah. Selain itu, pengetahuan yang diterima siswa secara pasif menjadikan matematika tidak bermakna bagi siswa. Data UN 2011 yang bersumber dari Puspendik Kemendiknas (2011) menyebutkan bahwa dari 45 sekolah negeri yang ada di Kabupaten Lampung Timur, nilai tertinggi adalah 9,75 dan nilai terendah 1,75 . Dari sumber yang sama, distribusi nilai siswa diperoleh $15,88 \%$ siswa memperoleh nilai masih dibawah ratarata. Salah satunya dari persentase penguasaan materi soal matematika UN 2011 SMP pada materi sistem persamaan linear dua variabel perolehan persentase nilai siswa 
Kabupaten Lampung Timur 65,11\%, Propinsi Lampung 72,54\%, dan Nasional 66,39\%. Data tersebut menunjukkan masih perlunya perbaikan kualitas pembelajaran matematika untuk meningkatkan prestasi belajar matematika siswa.

Pendekatan Matematika Realistik merupakan salah satu pendekatan pembelajaran matematika yang berorientasi pada matematisasi pengalaman sehari-hari dan menerapkan matematika dalam kehidupan sehari-hari. Sutarto Hadi (2005: 7) mengatakan bahwa PMR tidak dapat dipisahkan dari Institute Freudenthal yang diadopsi dari teori pembelajaran Realistic Mathematics Education (RME). Sejak tahun 1971, Institut Freudenthal mengembangkan suatu pendekatan teoritis terhadap pembelajaran matematika yang dikenal dengan $R M E$. RME menggabungkan pandangan tentang apa itu matematika, bagaimana siswabelajar matematika, dan bagaimana matematika harus diajarkan. Artikel yang ditulis oleh Barnes (2004) menyimpulkan bahwa $R M E$ telah memainkan peran dalam menggalang dan mengatasi konsepsi alternatif dari peserta didik. Hal ini dengan dilakukan terlebih dahulu melalui penerapan prinsip dipandu dalam desain masalah kontekstual. Masalah yang memulai proses dengan melihat peserta didik terlibat dalam matematisasi horisontal dan atau vertikal, yang kemudian menghasilkan konsepsi alternatif untuk dibahas dan ditangani

PMR yang dimaksudkan dalam hal ini adalah matematika sekolah yang dilaksanakan dengan menempatkan realitas dan pengalaman siswa sebagai titik awal pembelajaran. Masalahmasalah realistik digunakan sebagai sumber munculnya konsep-konsep matematika atau pengetahuan matematika formal. Pembelajaran PMR di kelas berorientasi pada karakteristik-karakteristik PMR, sehingga siswa mempunyai kesempatan untuk menemukan kembali konsepkonsep matematika atau pengetahuan matematika formal. Selanjutnya, siswa diberi kesempatan mengaplikasikan konsep-konsep matematika untuk memecahkan masalah sehari-hari atau masalah dalam bidang lain.

Di lain pihak, siswa memiliki kepribadian berbeda-beda. Kepribadian yang dimaksud adalah suatu ciri khas yang menetap pada diri seseorang dalam berbagai situasi dan dalam berbagai kondisi, mampu membedakan antara individu yang satu dengan individu lainnya. Dalam dunia pendidikan, sebagai seorang pendidik pasti akan dihadapkan pada berbagai karakteristik kepribadian, ada siswa yang menyenangkan, periang, terbuka terhadap permasalahan yang sedang dihadapinya, aktif, dan sebaliknya ada siswa yang terkesan membosankan, pendiam, tidak terbuka, tidak hangat dan lain sebagainya. Tentu saja sebagai 
seorang pendidik sangat dituntut untuk memahami karakteristik kepribadian setiap siswa, sehingga selaku pendidik dapat memberikan stimulasi atau perlakuan yang sesuai dengan tipe kepribadian siswa yang kita hadapi.Ada banyak tipe kepribadian, seperti diungkapkan oleh parah ahli. Salah satunya adalah tipe kepribadian menurut Hiprocates dan Gelanus. Hiprocates dan Gelanus membagi tipe kepribadian berdasarkan zat cair yang ada dalam tubuh seseorang. Mereka membagi tipe kribadian kedalam empat bagian. Seperti diungkapkan oleh Littauer (1996: 11) yaitu: Sanguinis, Melankolis, Koleris, dan Phlegmatis.

Lebih dari 400 tahun sebelum Masehi, Hippocrates, seorang tabib dan ahli filsafat yang sangat pandai dari Yunani,mengemukakan suatu teori kepribadianyang mengatakan bahwa pada dasarnya ada empat tipe temperamen. Sebenarnya, ada beberapa teori mengenai macam-macam kepribadian. Teori yang paling popular dan terus dikembangkan adalah teori Hipocrates-Galenus. Yang merupakan pengembangan dari teori Empedokretus.

Berdasarkan pemikirannya, ia mengatakan bahwa keempat tipe temperamen dasar itu adalah akibat dari empat macam cairan tubuh yang sangat penting di dalam tubuh manusia:

1. Sifat kering terdapat dalam chole (empedu kuning),

2. Sifat basah terdapat dalam melanchole (empedu hitam),
3. Sifat dingin terdapat dalam phlegma (lendir),

4. Sifat panas terdapat dalam sanguis (darah).

Kemudian teori Hippocrates disempurnakan kembali oleh Galenus yang mengatakan bahwa keempat cairan tersebut ada dalam tubuh dalam proporsi tertentu, dimana jika salah satu cairan lebih dominan dari cairan yang lain, maka cairan tersebut dapat membentuk kepribadian seseorang. Berpuluh tahun lamanya tipologi yunani yang bersifat filosofis ini berpengaruh luas sekali. Bahkan psikologi modern telah mengemukakan banyak saran baru mengenai penggolongan temperamen, tetapi tidak ada yang dapat menemukan penggolongan yang lebih bisa diterima seperti yang dikemukakan oleh Hippocrates dan Galenus.

Untuk memperoleh gambaran mengenai berbagai sifat temperamen yang melekat dalam setiap cairan, berikut adalah gambaran dari penggolongan manusia berdasarkan keempat bentuk cairan tersebut.

\section{Tipe Kepribadian Choleris}

Cairan yang lebih dominan dalam tubuh yaitu cairan chole. Dimana orang yang choleris adalah orang yang memiliki tipe kepribadian yang khas seperti hidup penuh semangat, keras, hatinya mudah terbakar, daya juang besar, optimistis, garang, mudah marah, 
pengatur, penguasa, pendendam, dan serius.

\section{Tipe Kepribadian Melancholis}

Cairan yang lebih dominan dalam tubuh yaitu cairan melanchole. Dimana orang yang melancholis adalah orang yang memiliki tipe kepribadian yang khas seperti mudah kecewa, daya juang kecil, muram, pesimistis, penakut, dan kaku.

\section{Tipe Kepribadian Phlegmatis}

Cairan yang lebih dominan dalam tubuh yaitu cairan phlegma. Dimana orang yang phlegmatis adalah orang yang memiliki tipe kepribadian yang khas seperti tidak suka terburu-buru, tenang, tidak mudah dipengaruhi, setia, dingin, santai dan sabar.

\section{Tipe Kepribadian Sanguinis}

Cairan yang lebih dominan dalam tubuh yaitu cairan sanguis. Dimana orang yang sanguinis adalah orang yang memiliki tipe kepribadian yang khas seperti hidup mudah berganti haluan, ramah, mudah bergaul, lincah, periang, mudah senyum, dan tidak mudah putus asa.

Terdapat beberapa tes yang dapat digunakan untuk menentukan tipe kepribadian yang dimiliki oleh seseorang. Salah satunya dengan menggunakan angket yang berisi karakter-karakter kepribadian yang akan menentukan tipe kepribadian seseorang. Dalam bukunya, Littauer
(1996: 13) memberikan tes kepribadian untuk menentukan tipe kepribadian seseorang termasuk dalam Sanguinis, Melankolis, Koleris atau Phlegmatis. Tes ini mempunyai 40 kriteria kepribadian siswa, masing-masing kriteria kepribadian terdapat 4 pilihan pernyataan yang dapat dipilih sesuai dengan karakter kepribadian siswa. Jawaban dari masing-masing kriteria kepribadian tersebut dicocokkan dengan kunci penilaian tipe kepribadian. Tipe kepribadian yang dipilih paling banyak atau yang mempunyai jumlah paling besar akan menentukan tipe kepribadian siswa. Berdasarkan keempat tipe kepribadian tersebut, dalam penelitian ini akan diambil tipe Sanguinisdan tipe Phlegmatis. Karena keduanya memiliki ciri dan karakter yang bertolak belakang, sehingga menarik untuk diteliti lebih lanjut.

Dari paparan di atas dilakukan penelitian yang bertujuan untuk mengetahui: (1) Mana yang lebih efektif, pembelajaran menggunakan metode diskusi dengan pendekatan matematika realistik (PMR) atau pembelajaran konvensional. (2) Mana yang memberikan prestasi belajar matematika lebih baik, siswa dengan tipe kepribadian Sanguinis atau Phlegmatis. (3) Mana yang lebih efektif untuk siswa pada masing-masingtipe kepribadian, pembelajaran menggunakan metode diskusi dengan pendekatan matematika realistik (PMR) atau pembelajaran konvensional. 


\section{METODE PENELITIAN}

Penelitian ini adalah penelitian eksperimental semu, karena terdapat beberapa variabel yang tidak mungkin untuk dikontrol. Variabel penelitian ini terdiri dari 2 variabel bebas, yaitu tipe kepribadian siswa dan metode pembelajaran, dan 1 variabel terikat yaitu prestasi belajar matematika pada materi sistem persamaan linear dua variabel. Rancangan yang digunakan dalam penelitian ini adalah rancangan faktorial $2 \times 2$.

Populasi dalam penelitian ini adalah seluruh siswa SMP Negeri kelas VIII di Kabupaten Lampung Timur Tahun Pelajaran 2012/2013yang terdiri atas 45 sekolah.Teknik pengambilan sampel dilakukan melalui sampling random stratifikasi berkelompok (stratified cluster random sampling), yaitu mengelompokkan populasi menjadi subpopulasi yang dianggap memiliki sampel. Diperoleh sampel penelitian SMPN 2 Way Bungur, SMPN 2 Sukadana, dan SMPN 2 Purbolinggo dengan jumlah sampel 202 siswa dengan rincian 101 siswa pada kelompok pertama dan 101 siswa pada kelompok kedua.

Teknik pengumpulan data yang dilakukan dalam penelitian ini, yaitu: (1) Metode dokumentasi,untuk memperoleh data mengenai sekolahsekolah yang akan dijadikan sampel penelitian dan data nilai Ujian Akhir Semester genap kelas VII tahun pelajaran 2011/2012 sebagai data kemampuan awal siswa. (2) Metode angket, angket tipe kepribadian siswa. Angket yang digunakan diadopsi dari buku Personality Plus karangan Florence Littauer, yang disesuaikan untuk siswa sekolah menengah. (3) Metode tes, tes tertulis yang digunakan berbentuk uraian.Sementara untuk menganalisis data dalam penelitiandigunakan uji hipotesis. Uji hipotesis dalam penelitian ini meliputi: (1) Uji Normalitas menggunakan metode Lilliefors, (2) Uji Homogenitas menggunakan metode Bartlett, (3) Uji Keseimbangan menggunakan Analisis Variansi (Anava) satu jalan dengan sel tak sama, (4) Analisis Variansi (Anava).

\section{HASIL PENELITIAN DAN PEMBAHASAN}

Setelah dilakukan uji keseimbangan untuk mengetahui kemampuan awal masing-masing kelompok adalah sama, selanjutnya dilakukan uji hipotesis penelitian. Rerata masing-masing sel dan rerata marginal dapat dilihat pada Tabel 1, sedangkan komputasi analisis variansi dua jalan dengan sel tak sama disajikan dalam Tabel 2.

Tabel 1. Rerata masing-masing sel dan Rerata Marginal 


\begin{tabular}{|c|c|c|c|}
\hline \multirow{2}{*}{$\begin{array}{c}\text { Tipe } \\
\text { Kepribadian } \\
\text { (A) }\end{array}$} & \multicolumn{2}{|c|}{$\begin{array}{c}\text { Metode Diskusi dengan Pendekatan } \\
\text { Pembelajaran(B) }\end{array}$} & $\begin{array}{c}\text { Rerata } \\
\text { Marginal }\end{array}$ \\
\cline { 2 - 3 } & PMR $\left(\mathrm{b}_{1}\right)$ & Konvensional $\left(\mathrm{b}_{3}\right)$ & \\
\hline Sanguinis $\left(\mathrm{a}_{1}\right)$ & 76,3214 & 73,7647 & 75,0431 \\
\hline Phlegmatis $\left(\mathrm{a}_{4}\right)$ & 75,9412 & 73,3125 & 74,6268 \\
\hline Rerata Marginal & 76,1313 & 73,5386 & 74,8349 \\
\hline
\end{tabular}

Tabel 2. Rangkuman Analisis Variansi Dua Jalan Sel Tak Sama.

\begin{tabular}{|l|c|c|c|c|c|c|}
\hline \multicolumn{1}{|c|}{ Sumber } & JK & $\mathbf{d k}$ & $\mathbf{R K}$ & & & $\begin{array}{c}\text { Keputusan } \\
\text { Uji }\end{array}$ \\
\hline $\begin{array}{l}\text { Tipe } \\
\text { Kepribadian (A) }\end{array}$ & 10,1072 & 3 & 3,3691 & 0,2715 & 2,60 & $H_{0}$ diterima \\
\hline Pendekatan (B) & 499,9811 & 2 & 249,9906 & 20,1455 & 3,00 & $H_{0}$ ditolak \\
\hline Interaksi (AB) & 21,0532 & 6 & 3,5088 & 0,2828 & 2,01 & $H_{0}$ diterima \\
\hline Galat & 3611,099 & 291 & 12,4093 & - & - & - \\
\hline Total & 4142,241 & 302 & - & - & - & - \\
\hline
\end{tabular}

Berdasarkan Tabel 2 dapat disimpulkan sebagai berikut: (a) Tipe kepribadian siswa tidak berpengaruh terhadap prestasi belajar matematika siswa. (b) Metode pembelajaran berpengaruh terhadap prestasi belajar matematika siswa. (c) Tidak ada interaksi antara tipe kepribadian siswa dan metode diskusi dengan pendekatan pembelajaran.

Dari hasil perhitungan anava diperoleh bahwa $\mathrm{H}_{\mathrm{OB}}$ ditolak, berarti tidak semua pendekatan pembelajaran memberikan pengaruh yang sama terhadap prestasi belajar matematika siswa. Karena pendekatan pembelajaran memiliki dua nilai maka dengan menggunakan rerata marginalnya dapat dilihat metode pembelajaran mana yang lebih baik.
Dari rerata marginal diperoleh pembelajaran menggunakan metode diskusi dengan pendekatan matematika realistik (PMR) memiliki rerata 76,1313. Sedangkan dengan menggunakan pembelajaran konvensional memiliki rerata 73,5386 . Hal ini menunjukkan kesimpulan metode diskusi dengan pendekatan pembelajaran PMR dan pendekatan pembelajaran konvensional memiliki efektivitas yang berbeda untuk meningkatkan prestasi belajar matematika siswa. Rerata prestasi belajar matematika siswa pada pembelajaran menggunakan metode diskusi dengan pendekatan pembelajaran PMR lebih tinggi dibandingkan pembelajaran menggunakan metode diskusi dengan pendekatan pembelajaran konvensional. 
Berarti pembelajaran menggunakan metode diskusi dengan pendekatan pembelajaran PMR lebih efektif dari pada pendekatan pembelajaran konvensional untuk meningkatkan prestasi belajar matematika siswa

Hasil dari penelitian ini sejalan dengan penelitian yang dilakukan oleh beberapa peneliti sebelumnya. Penelitian oleh Nelly Fitriani (2012) menyimpulkan kemampuan pemecahan masalah matematis siswa yang memperoleh pembelajaran dengan menggunakan pendekatan PMR secara berkelompok lebih baik daripada siswa yang memperoleh pembelajaran konvensional. Begitu juga Sigid Edy Purwanto (2010) menyimpulkan bahwa terdapat perbedaan yang signifikan antara kemampuan pemecahan masalah matematis siswa pada kelompok PMRdan kelompok kontrol. Kemampuan pemecahan masalah matematis siswa yang telah mengikuti PMR lebih baik dari pada siswa yang mengikuti pembelajaran konvensional.

Berdasarkan Tabel 2 diketahui bahwa tipe kepribadian siswa tidak berpengaruh terhadap prestasi belajar siswa. Hal ini sesuai dengan penelitian Heni Mularsih (2010) yang menyebutkan tidak ada perbedaan yang signifikan antara hasil belajar siswa dengan tipe kepribadian siswa. Selanjutnya, dari Tabel 2 juga dapat disimpulkan bahwa tidak terdapat interaksi antara pembelajaran menggunakan metode diskusi dengan pendekatan pembelajaran dan tipe kepribadian siswa terhadap prestasi belajar matematika. Kesimpulan penelitiannya adalah siswa pada masing-masing tipe kepribadian, pembelajaran menggunakan metode diskusi dengan PMR lebih efektif dibandingkan pembelajaran matematika menggunakan metode diskusi dengan pendekatan pembelajaran konvensional.

\section{KESIMPULAN DAN SARAN}

Berdasarkan analisis data dari penelitian yang dilakukan, dapat disimpulkan sebagai berikut:

Pembelajaran matematika menggunakan metode diskusi lebih efektif dibandingkan pembelajaran matematika menggunakan metode diskusi dengan pendekatan pembelajaran konvensional. (2) Siswa dengan Tipe Kepribadian Sanguinismaupun Plagmatis memiliki prestasi belajar matematika yang sama. (3) Siswa pada masing-masingtipe kepribadian, pembelajaran menggunakan metode diskusi dengan PMR lebih efektif dibandingkan pembelajaran matematika menggunakan metode diskusi dengan pendekatan pembelajaran konvensional.

Beberapa hal yang perlu peneliti sarankan, yaitu: (1) Dalam pembelajaran matematika tidak semua materi baik disampaikan dengan pendekatan konvensional. Oleh karena 
itu, perlu adanya pemilihan pendekatan yang tepat dengan materi. Pada penelitian ini menghasilkan pendekatan pembelajaran dengan PMR lebih efektif daripada pembelajaran kontekstual, sehingga guru disarankan menerapkan pendekatan pembelajaran PMR untuk pembelajaran di kelas terutama pada materi Sistem Persamaan Linear Dua Variabel. (2) Selain dari pendekatan pembelajaran yang digunakan, guru juga dapat memperhatikan masingmasing karakter siswa melalui tipe kepribadian siswa. Salah satunya tipe kepribadian siswa seperti pada penelitian ini. Siswa dengan tipe kepribadian Sanguinisdan Phlagmatis akan lebih efektif dan menghasilkan prestasi belajar matematika lebih baik jika diajar dengan pembelajaran menggunakan metode diskusi dengan PMR. (3) Kepada para peneliti untuk melakukan pengkajian lebih mendalam dan secara luas mengenai pengaruh pembelajaran dengan pendekatan PMR dan $Q L$, serta kaitannya dengan Tipe Kepribadian siswa terhadap hasil belajar siswa di SMP, khususnya di Kabupaten Lampung Timur.

\section{DAFTAR PUSTAKA}

Barnes, H. 2004. Realistic mathematics education: Eliciting alternative mathematical conceptions of learners. African Journal of Research in SMT Education, Volume 8 (1), pp. 53-64.
Diunduh dari http://p4mristkipgarut. files.wordpress.com/2010/11/real istic-mathematics-education eliciting-alternativemathematical -conceptions-oflearners-hayley-barnes.pdf pada 21 Juli 2012.

Feza-Piyose, N. 2012. Language: A Cultural Capital For Conceptualizing Mathematics Knowledge. Human Sciences Research Council, South Africa. International Electronic Journal of Mathematics Education. Vol. 7, No. 2, pp. 67-79.

Heni Mularsih. 2010. Strategi Pembelajaran, Tipe Kepribadian Dan Hasil Belajar Bahasa Indonesia Pada Siswa Sekolah Menengah Pertama. Makara, Sosial Humaniora, Vol. 14, No. 1, 65-79. Diunduh dari http://journal.ui.ac.id/ index. php/humanities/article/viewFile/5 73/569 pada11 Januari 2013.

Littauer, F. 1996. Personality Plus: (Kepribadian Plus). Jakarta: Binarupa Aksara.

Nelly Fitriani. 2012. Penerapan Pendekatan Pendidikan Matematika Realistik secara Berkelompok untuk Meningkatkan Kemampuan Pemecahan Masalah Matematis dan Self Confidence Siswa SMP: Studi Kuasi Eksperimen pada Siswa Kelas VIII Salah Satu SMP Negeri di Ngamprah. Tesis. UPI. Bandung. Diunduh dari http://repository. 
upi.edu/tesisview.php?

no tesis=2 pada 21 Juli 2012.

Pusat Penilaian Pendidikan. 2011. Pemanfaatan Hasil Ujian Nasional untuk Perbaikan Mutu Pendidikan. Jakarta: Kementrian Pendidikan Nasional.

R. Soedjadi. 2000. Kiat Pendidikan Matematika di Indonesia. Jakarta: Direktorat Jendral Pendidikan Tinggi.
Sigid Edy Purwanto. 2010. Meningkatkan Kemampuan Pemecahan Masalah Matematis Siswa SMP dan MTs melalui Pembelajaran Matematika Realistik. Disertasi. UPI. Bandung. Diunduh dari http://repository.upi.edu/ disertasiview.php? no disertasi $=233$ pada 21 Juli 2012.

Sutarto Hadi. 2005. Pendidikan Matematika Realistik dan Implementasinya. Banjarmasin: Tulip. 